\title{
The equity implications of TOD in Curitiba
}

\author{
André L. B. Turbay \\ Pontifícia Universidade Católica do Paraná (PUCPR),Brazil \\ Rafael H. M. Pereira \\ Institute for Applied Economic Research (Ipea), Brazil \\ Rodrigo Firmino \\ Pontifícia Universidade Católica do Paraná (PUCPR),Brazil
}

\begin{abstract}
Transit Oriented Development (TOD) projects are being increasingly adopted worldwide as a way to coordinate transport and land-use planning. However, little attention has been given to how TOD projects are associated with socioeconomic and spatial inequalities and its effects on people's access to economic activities and public services. In this paper we analyze how socio-spatial inequalities have been shaped by transport and land-use planning in Curitiba (Brazil), a city recognized for its TOD planning based on Bus Rapid Transit (BRT). We examine how the spatial organization of the BRT system is associated with population densities, socioeconomic groups, and real-estate values and its implications in terms of inequalities of access to employment opportunities and health services. The results show that Curitiba's TOD has had limited influence on population densities, but has shaped the concentration of high-income classes and premium real-estate along its main BRT corridors. These effects contribute to push low-income communities to peripheral urban areas with limited accessibility benefits from the transit system. Our findings suggest that Curitiba's success story should be seen as a cautionary tale about the consequences of TOD planning, which perpetuate the spatial concentration of resources and reinforce inequalities of access to opportunities. The broader lesson of this study is that TOD planning must be constantly evaluated by its socials and environmental impacts, and be guided by mixed housing, and social inclusion to avoid segregation and peripheralization of poorer communities.
\end{abstract}

Keywords: Transit-oriented development, equity, accessibility, Curitiba, Bus Rapid Transit.

\footnotetext{
*Corresponding author: andre.turbay@pucpr.br
} 


\section{Introduction}

Curitiba is known worldwide for what is today considered one of the first comprehensive implementations of a Transit Oriented Development (TOD) Master Plan (Duarte et al., 2011; Lindau et al., 2010). Curitiba's TOD was planned in the 1960s as a comprehensive urban policy built around transit corridors which were used to organize and induce linear urban expansion according to strict land-use regulations (Oba, 2004; Mercier et al., 2015). The system enabled by a Bus Rapid Transit (BRT) network was considered innovative by urban and transport planners across the world (Cervero, 1998; ICLEI, 2016; Khayesi \& Amekudzi, 2011), and it is still the basis for the city's international reputation as a reference for urban planning (Nakamura et al., 2017; de Freitas Miranda \& da Silva, 2012; PMI, 2019). Nonetheless, with all the praise for the close coordination between transport and land-use planning, much less attention has been given to the effects of such a system upon the socioeconomic and spatial distribution of the benefits of TOD in Curitiba (Duarte \& Ultramari, 2012). There is little critical understanding of the equity implications of Curitiba's TOD in terms of its role in contributing to shape socio-spatial inequalities in the distribution of land values, socioeconomic classes, and transport inequalities.

This paper examines the association between Curitiba's TOD strategy and socioeconomic and transport inequalities. We analyze how the organization of the BRT network relates to uneven spatial distribution both of population densities, land values and of social classes, and how it contributes to shape the extent to which different income groups benefit from Curitiba's BRT in terms of transit accessibility. Using detailed estimates of transit accessibility to employment opportunities and healthcare services, we show how the accessibility benefits of TOD have disproportionately favored high-income groups, reflecting important inequitable outcomes from TOD models in the long term. Using detailed cross-sectional data on land values at parcel level, and spatial distribution of socioeconomic groups, employment opportunities and healthcare services, we examine the relationship between the city's TOD strategy and land values along Curitiba's BRT main axes and its spatial implications for unequal access to opportunities and socio-spatial segregation. 
The remainder of this paper is organized as follows. Section two presents a review of the literature on the concepts of TOD and its relationship with accessibility and transportation equity. Section three presents the historical context of Curitiba's TOD implementation and its BRT network. Section four describes the data and methods used in this study. In section five we present our findings on the spatial association between the BRT network and distribution of population densities, socioeconomic groups, real-estate values and transit accessibility. Finally, in section six we discuss some of the main findings of this study and reflect on what broader lessons about TOD and inclusive planning can be drawn from Curitiba and applied to other contexts.

\section{TOD, urban accessibility and equity}

Transit-Oriented Development (TOD) has been proposed by several authors as an effective alternative for the promotion of urban sustainability (Calthorpe, 1994; Cervero, 1998; Cervero \& Sullivan, 2011; Qviström \& Bengtsson, 2015; Loo \& du Verle, 2017). The integration between transport and land use policies is seen as key ingredient for promoting accessibility, active mobility, and public transport (Banister, 2011; Cervero, 2014).

The concept Transit-oriented Development (TOD) emerged in the context of the New Urbanism movement in the USA in the late $20^{\text {th }}$ century, in a publication on the ecology of communities (Jamme et al, 2019; Carlton, 2009). The essential idea of TOD is for compact urban development to be driven by mixed land use along mass-transit corridors that promotes proximity between housing, services, economic activities, and amenities, contributing to higher accessibility levels and social equity (Calthorpe, 1994; Dittmar \& Poticha, 2004).

Some of the main benefits of TOD discussed in the literature would be to reduce the dependency on motor vehicles, achieved through a combination of mixed communities and proximity between people, activities and transport services (Bernick \& Cervero, 1997; Dittmar \& Poticha, 2004, Carlton, 2009). Provision of public transport, walkable infrastructure and proximity between residential and commercial use are factors that can lead to reduced car use and higher levels of transit accessibility to opportunities (Boschmann \& Brady 2013; Taki et al., 2017; Cervero \& 
Dai, 2014; Perk \& Catalá, 2009). Because of these benefits, several studies argue that TOD strategies can foster more inclusive cities and equitable transit systems with lower car dependency and greater access to opportunities for all communities (Calthorpe, 1994; Chava et al., 2018; Jamme et al, 2019; Appleyard et al., 2019; Lyu et al., 2020). On the other hand, some studies suggest that the implementation of TODs often have negative in terms of increasing land prices and segregation of social classes along TOD corridors (Padeiro et al., 2019; Chava et al., 2018), and pushing low-income communities to urban peripheral areas (Saunders \& Smith, 2014; Jamme et al., 2019).

Traditionally, the discussions around TOD often focus on access to transit as a way to increase transit ridership, tackle traffic congestion, and create socially cohesive urban neighborhoods (Deboosere et al. 2018). More recently, though, there has been a growing interest in how TOD can promote equal access to opportunities (Papa \& Bertolini, 2015; Renne et al 2016; Lyu et al., 2020) and on what social equity implications it could have (Venter et al 2018; Jamme et al., 2019). There is a growing consensus that accessibility is one of the main benefits catered by public transport systems (van Wee, 2016; Handy, 2020; Levine, 2020). Accessibility is defined as the ease with which people can reach opportunities for interaction with economic activities, public services, leisure activities, etc. (Van Wee \& Geurs, 2011; Geurs et al., 2015). A person's or neighborhood's levels of accessibility are fundamentally shaped by the integration between transport and land use systems, which can make it easier or harder for individuals and social groups to reach activities and destinations (Van Wee \& Geurs, 2011; Geurs et al., 2015; Wee, 2016; Xu et al., 2018). Particularly since the 2000s, the concept and methods of accessibility have been increasingly used to articulate the integration between urban and transport planning and its implications to social equity, economic development, and environmental impact (Feitelson, 2002; Mattioli, 2016; Boisjoly \& Geneidy, 2017; Levinson \& King, 2020).

The promotion of equity in transport planning is largely centered around the organization of urban environments and transit systems that increase access to economic activities, services, and amenities, particularly for vulnerable communities (Lucas et al., 2016; Pereira \& Karner, 2021). Transport accessibility plays a key role as a mediator for individuals to satisfy their basic needs, to participate in social and economic life and as a determining factor of personal freedom (van Wee \& Geurs, 
2011; Martens, 2016; Pereira et al., 2017; Allen \& Farber, 2020). As some authors have argued, accessibility is an essential component for of social justice and social inclusion that constitute the right to the city (Fol \& Gallez, 2014; Pereira et al., 2017; Verlinghieri \& Schwanen, 2020). As such, TOD, as a land use and mass transit mixing policy, can importantly contribute to reducing inequalities in access to opportunities, a key egalitarian concern in the transportation equity literature (Pereira et al 2017, Lucas et al 2016).

In summary, there is a tension in the literature about the potential implications of TOD for the promotion of inclusive cities. On the one hand, the conceptual proposal of TODs is geared towards the promotion of mixed and inclusive neighborhoods that promotes urban accessibility by active and public transport modes. On the other hand, some previous experiences suggest that the uneven spatial impacts of TOD projects seem to shape real-estate markets in ways that push low-income populations away from the accessibility benefits of TOD. Next, we see how this tension has played out in Curitiba, one of $1^{\text {st }}$ large-scale TOD plans in the world.

\section{Curitiba's TOD}

Curitiba is a city of two million inhabitants in the south of Brazil. It is the hub city of a Metropolitan region with 29 municipalities and an estimated population of 3.7 million. The city is recognized worldwide for its pioneer experience with TOD urban planning, especially for its green spaces and transport system (Rabinovitch \& Leitman, 1996; Macedo, 2004). This recognition is due to a confluence of factors (Ardila-Gomez, 2004; Stewart, 2014), including the master plans of the 1940s and 1960s, known as the Plano Agache, and the Plano Preliminar de Urbanismo, respectively. This latter led to urban planning structured according to a linear development in line with TOD principles (Oba, 2004; Duarte et al., 2011; Mercier et al., 2015).

Curitiba's urban development is guided by its mains transport corridors, known as 'structural axes', that combine high density and mass transport. These corridors are served by a road-based BRTs running on exclusive lanes. Curitiba's implementation of this system led to its recognition as the birthplace of the BRT 
(Lindau et al., 2010), and culminated in the current full BRT ${ }^{1}$ system (Duarte \& Rojas, 2012). In practice, Curitiba was planned around TOD model based on BRT as transport technology (Cervero,1998; Cervero, 2014; Suzuki et al., 2013; Hidalgo et al., 2019).

It is nearly fifty years since the implementation of Curitiba's TOD strategy and BRT system. Over the decades, the TOD and BRT have affected socio-spatial distribution and the forms of the population's mobility. Despite the expansion of the BRT network in Curitiba, the city has been witnessing constant decline in the number of users of public transport in recent years, from 1.6M in 2015 to $1.3 \mathrm{M}$ in 2019 (URBS, 2021; Duarte et al., 2011). Of the 1,3M public-transport users in 2019, 721 thousand (approximately 55\%) used the BRT system (URBS, 2022).

According to the latest household travel survey of Curitiba (IPPUC, 2017), 25,2\% of all daily trips in the city were made by transit. This share is significantly lower for medium- (15,9\%) and high-income (7,7\%) families. According to these data, the use of private motorized vehicles in Curitiba is much higher among high-income classes, who generally live (see section 5.2). closer to the main TOD axes. By contrast, the most frequent users of public transportation in Curitiba do not live near the BRT corridors (IPPUC, 2017; Duarte \& Ultramari, 2012).

Recent studies on transport accessibility in Curitiba have found pronounced socio-spatial inequalities in access to work, education, and healthcare (Pereira et al, 2019; Bittencourt et al., 2020; Boisjoly et al., 2020). The city that is recognized worldwide for the implementation of BRT and TOD corridors seems to present a scenario of mobility and accessibility characterized by inequality. The question that arises, and which will be explored in section 5, concerns how much Curitiba's planning favors or reinforces unequal socio-spatial distribution.

\subsection{Origins and spatialization of Curitiba's TOD}

The decision towards Curitiba's TOD happened in the 1960s, at a time of highdensity central areas and disordered and scattered radial growth (Curitiba, 1965;

\footnotetext{
1 "The main characteristics of Curitiba's BRT...include bus platforms at the same level as the floor of the bus; speedy boarding and alighting; prepaid fares; automated fare collection; greater spacing between bus stops (from $500 \mathrm{~m}$ up to $3 \mathrm{~km}$ ); and integration of trunk and feeder lines in main stations: (DUARTE \& ROJAS, 2012, p. 3)
} 
Polucha, 2009). What was known as the Plano Preliminar de Urbanismo, devised in 1964 and established in law in the 1966 Masterplan, redefined Curitiba's land use and occupation according to two linear axes of densification that defined new zones of occupation when the city population stood at approximately 500 thousand (IBGE, 2010). The 1966 plan determined the preferred high-density zones intended for mixed use, linear distribution of the main public-transport corridors, and the road system of high-speed avenues. This association between express bus lanes (BRT), high density and the promotion of mixed use of the structural axes characterizes the Curitiba TOD (Figure 1).

\section{Figure 1 - Schematic drawings of the relationship between transport corridor and densities in Curitiba}

\section{STRUCTURAL AXES}

high density + integrated uses

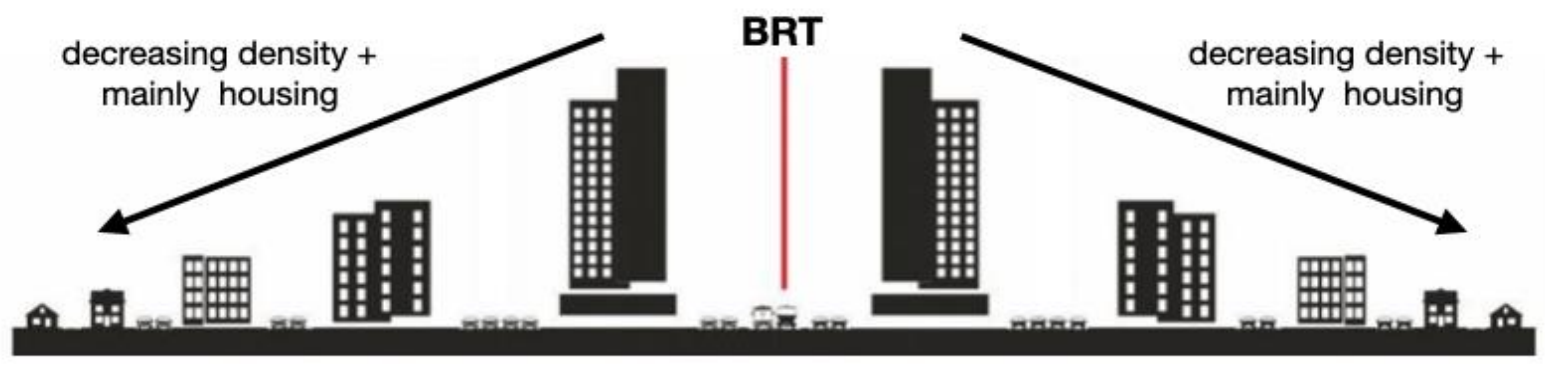

Source: Prepared by the authors based on ANTP (2021).

Curitiba's BRT corridors can essentially be classified into three types based on their different characteristics with regards to land-use and occupation guidelines. The first type is defined by the structural axes, the official term in Curitiba's current urban legislation to define the transport corridors served by express BRT services. This type is characterized by TOD attributes, as high density with construction limits of four times the lot area and promotion of mixed use with commercial ground floors, covered galleries for pedestrian circulation, and the topmost floors dedicated to residential use. This type of BRT corridor, the North-South and East-West axes (Figure 2), was presented in the original 1966 Masterplan.

The second type of BRT corridor is focused on service zones and is called by local legislation as "Special Axes", with construction limit of one and a half times the lot size for services and single lot size for residential use. Unlike the first type of BRT corridor, this occupation model does not allow different land uses on the same lot, but 
determines urban zones specifically given over to services and residential use separated by the BRT corridors. This use and occupation model applies to the Boqueirão axis implemented in the late 1970s and the Circular Sul completed in 1999 (Type 2 in Figure 2).

The third and final type of Curitiba's BRT corridors features construction limits of twice lot size for residential use and single lot size for commercial use, which indicates planning for mixed use with a priority for housing. This type of land-use regulation applies to the Linha Verde corridor, a new BRT axis whose construction started in 2004 and is still under construction. The purpose of Linha Verde is to transform a former federal highway with primarily industrial and service use into a mixed-use, medium-density urban area with an emphasis on mixed-use (Figure 2).

In sum, the TOD Curitiba is represented by one of three types of BRT corridors with widely different characteristics in terms of land use and construction limits. The corridor known as structural axis (type 1) is the closest to a full implementation of a TOD, with integrated high density and mixed use. The other BRT corridors (types 2 and 3) are distinguished, almost solely, by the presence of the mass transit infrastructure, with no zoning patterns oriented to high density.

Figure 2. Map of Curitiba's TOD / BRT corridors by type. 2019.

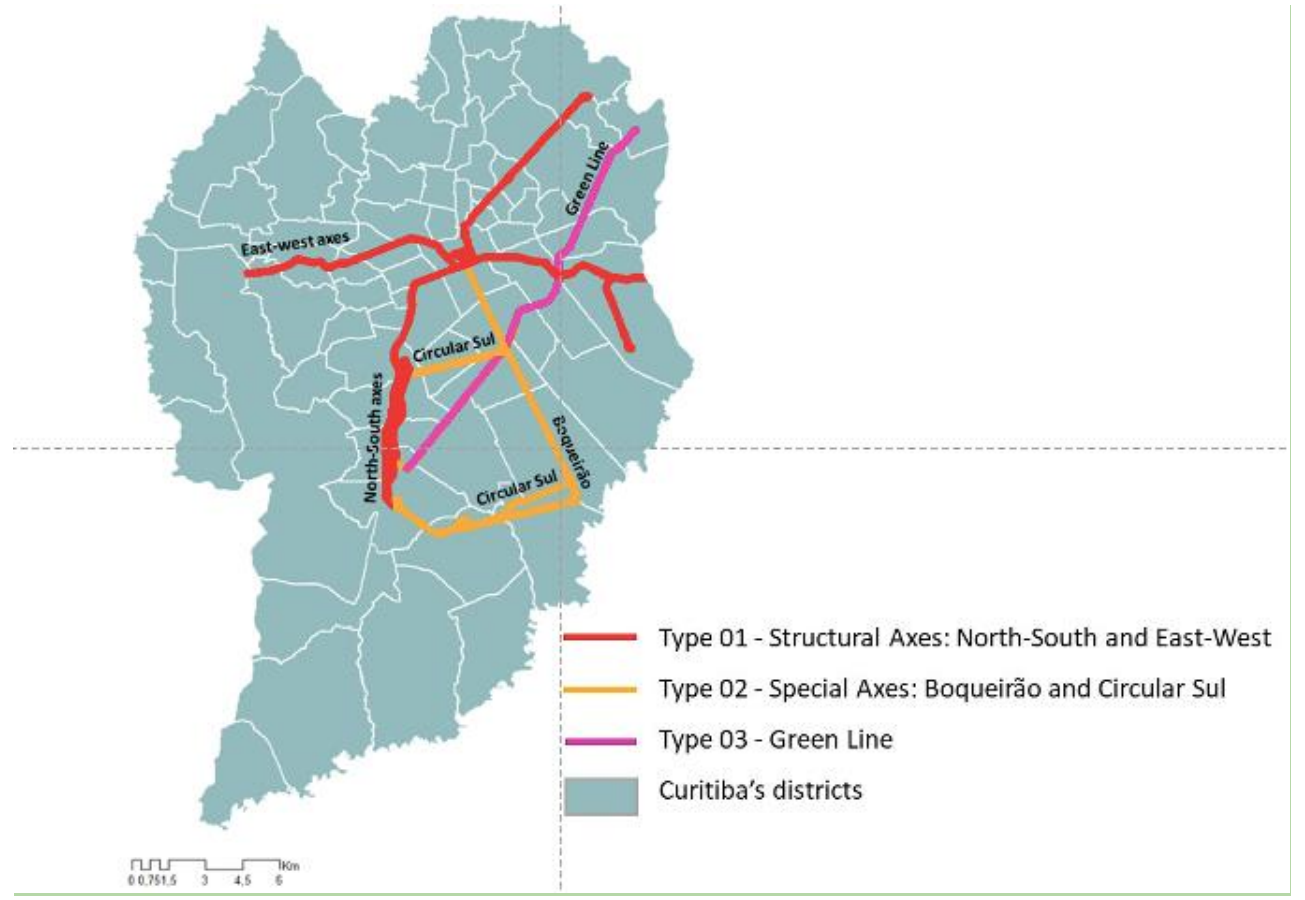

Source: Prepared by the authors based on URBS (2021) transit network information and IPPUC (2019) land price. 


\section{Data and methods}

In this paper we analyze how Curitiba's BRT corridors are associated with the spatial distribution of population densities and socioeconomic groups, together with the distribution of real-estate values and inequalities in transit access to employment and health services.

\subsection{Data}

High resolution land-value data for 2019 come from the Real Estate Registry and Curitiba's local government map of property values ${ }^{2}$. The data set provides parcellevel information on land values used by the local government for urban planning and tax management purposes. Although this data set does not follow market values in real time, it does provide a good picture of how real-estate values vary across the city and real-estate units.

All the data on population, socioeconomic characteristics, land use and accessibility estimates used in this paper were originally generated by the Access to Opportunities Project (Pereira et al. 2019). These data were made publicly available by the authors at $<<$ https://github.com/ipeaGIT/aopdata $>>^{3}$. We describe below the data sources and methods deployed by Pereira et al. (2019).

The method used in the project combined data from national household surveys, administrative records from federal and municipal governments, satellite images and collaborative mapping data to estimate accessibility at a high spatial resolution. The project divides Curitiba's territory into hexagonal cells, as the spatial unit of reference for aggregation of demographic, land-use and accessibility estimates. The analysis was based on a hexagonal grid corresponding to the global $\mathrm{H} 3$ index at resolution 9, with an area of $0.11 \mathrm{~km}^{2}$; this is the approximate size of a typical city block ${ }^{4}$.

Population and socioeconomic data processed by Pereira et al. (2019) come from the latest Brazilian population census, conducted in 2010. Data on per-capita

\footnotetext{
2 Available at http://geoapp.ippuc.org.br/plantagenericadevalores/

3 More information about the Access to Opportunities Project and its databases are available at: https://www.ipea.gov.br/acessooportunidades/en/

${ }_{4}^{4}$ More info about the $\mathrm{H} 3$ indexing system at https://h3geo.org/docs/core-library/restable
} 
household income were extracted from census figures, while population count data were extracted from a regular 200-meter grid (IBGE, 2016). These data were spatially re-aggregated using dasymetric interpolation to calculate the number of residents and average per-capita household income for each hexagonal cell.

Data on formal employment provided by Pereira et al. (2019) come from the Ministry of Labor's 2019 Annual Report on Social Information (RAIS), covering all companies with more than 10 employees. Public jobs were excluded from the analysis because of systematic inconsistencies in the addresses reported by the public sector. Geolocated data on healthcare facilities for 2019 come from the National Register of Health Care Facilities (CNES), which covers all free primary, ambulatory care and hospital services through the public health system (SUS). Data sets for job opportunities and healthcare facilities were both geocoded and made publicly available by Pereira et al. (2019).

Finally, transport information was based on GTFS transit data from October 2019, provided by Curitiba's urban planning company (URBS). These data were processed with street network data from OpenStreetMap using OpenTripPlanner (OTP) to generate accessibility estimates.

\subsection{Accessibility estimates}

Accessibility indicators are commonly used in urban and transport studies to indicate the ease with which people can reach places or opportunities (Van Wee; Geurs, 2011). This paper uses the accessibility estimates based on the number of employment opportunities and healthcare facilities reachable by public transport within 30, 60, 90 and 120 minutes. These data were made available by Pereira et al (2019), and reflect how easily individuals could access these essential activities by transit.

This indicator is known as the cumulative opportunity measure, presented in Equation 1. This accessibility measure is one of the most widely used accessibility metrics in transport planning and equity analysis, because it is easily calculated and interpreted by policy makers (Boisjoly \& El-Geneidy, 2017; Manaugh et al., 2015).

We considered a travel-time threshold of 60 minutes, which seems a good to fit travel behavior in Curitiba given the average travel patterns in the city. The latest 2016 household travel survey (IPPUC, 2017) indicates that public-transport journeys to work 
and health services in the city of Curitiba took an average of 52 and 51 minutes respectively.

$$
C M A_{\text {oTP }}=\sum_{o=1}^{n} P_{d} f\left(t_{o d}\right)
$$

Where:

$C M A_{\text {отP }}$ is the active cumulative opportunity estimate from origin $o$ within time threshold $T$ to the opportunity $P$

$P_{d}$ is the number of opportunities (jobs, healthcare facilities or schools) in destination $d$ $t_{o d}$ is the travel time (minutes) from origin $o$ to destination $\mathrm{d}$

$f\left(t_{o d}\right)$ is a time threshold function that varies between one and zero, depending on whether travel time is larger or smaller than time threshold $T$

In the next section we use these data and methods to examine how Curitiba's BRT corridors are associated with the spatial distribution of real-estate values, population density and income levels, together with how these corridors shape social and spatial inequalities of access to opportunities. The code to reproduce the data analysis and figures presented in this paper was written in $\mathrm{R}$ it is available at $<<$ link not disclosed yet to preserve the authors' identities >>.

\section{TOD and urban spatial inequalities}

\subsection{Population density and TOD in Curitiba}

One of the main objectives of the TOD plan adopted by Curitiba is the orientation of population density along the transport axes. Despite decades of land-use policies in Curitiba allowing greater construction potential along the structural axes, the consolidation of higher population density can only be seen in those sections of TOD near the city center (Figure 3A). Figure 3B shows a slightly higher population densities in areas up to 300 meters from the BRT corridors. But between 300 meters and 10 $\mathrm{km}$, densities remain constant. In short, the proposal of linear urban growth determined by high construction potential along the structural axes occurred to a limited extent in the TOD corridor, mainly in the areas nearest the city center. 
The low density along most of the BRT corridors indicates that flexible legislation with greater construction limits along the corridors has not been sufficient to promote higher densities. This also suggests that Curitiba's TOD policies have not managed to stimulate the full occupation of the structural axes, beyond real state natural interest. On the North axis, for example, only $10 \%$ of the construction potential has been realized according to planned density limits (Penteado et al., 2019, p. 14). The low population density along the non-central areas of structural axes and the current higher rates of demographic growth in peripheral areas, not served by BRT shows that the policy of linear density works only in central high-income areas, and that it is not oriented to mixed housing. This situation raises questions about the extent to which the planning orientation to densify the structural axes is enough to induce the occupation, and why the occupation of TOD corridors is limited to central areas.

Figure 3. (A) Spatial distribution of population density, and (B) relationship between population density and distance to the nearest BRT corridor, Curitiba, 2019.

A

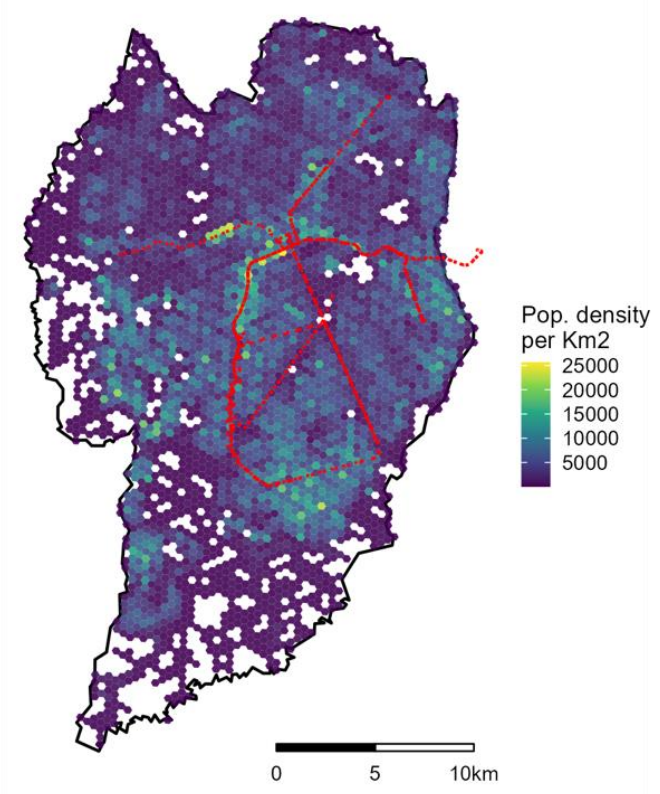

B

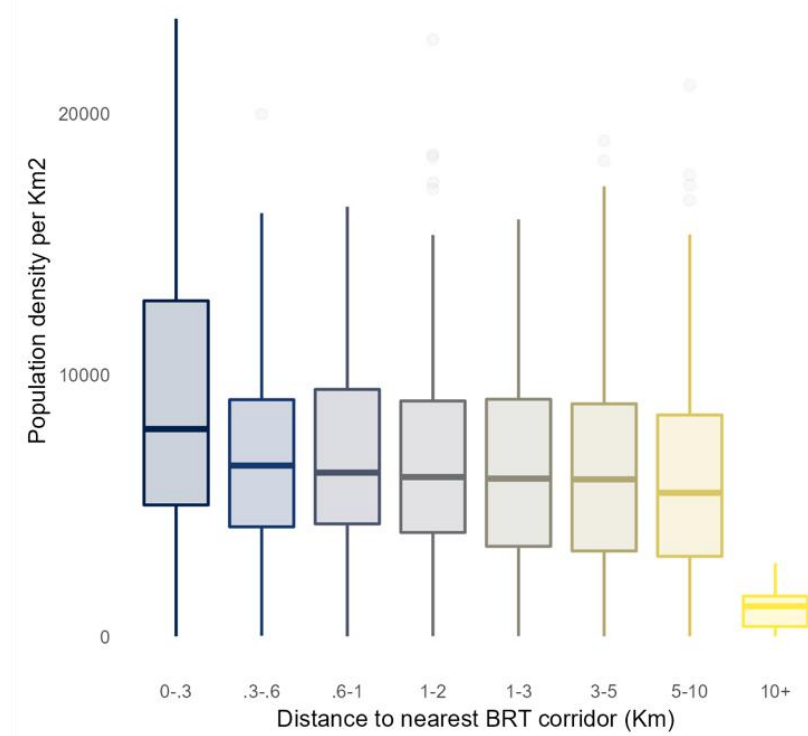

Source: population data 2010 census (IBGE) and BRT corridors operational in 2019.

\subsection{Spatial distribution of income levels and TOD in Curitiba}

The spatial distribution of construction potential and BRT corridors defined in Curitiba's TOD have an important relationship with the spatial distribution of income groups in the city. Most of the highest-income residents live near the city center and the TOD 
(BRT Type1) corridors (Figure 4A). Meanwhile the low-income population is mainly located in the peripheral regions not covered by the BRT networks, which entails lower access to the mass transit system.

Figure 4B also shows the relationship between income levels and proximity to the TOD axis. Although some high-income neighborhoods are further from the BRT system, an inverse relationship can clearly be seen between income and distance from the BRT system. The higher the income level, the nearer the population is to Curitiba's BRT system. On the periphery, where population growth has been highest since 2000, there is no BRT and income levels are substantially lower (IPPUC, 2012).

Figure 4. (A) Spatial distribution of population by income deciles, and (B) relationship between population income and distance to the nearest BRT corridor, Curitiba, 2019.

A

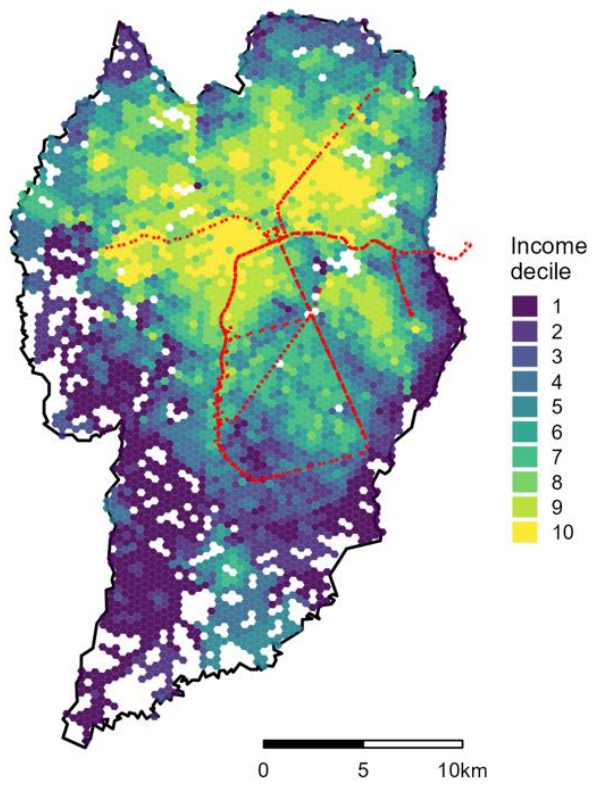

B

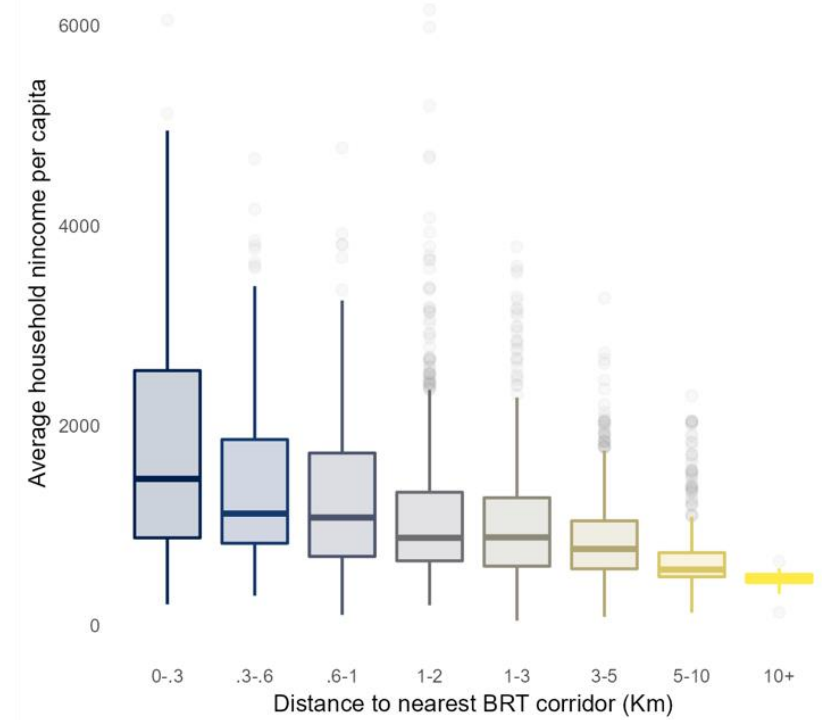

Source: population data 2010 census (IBGE) and BRT corridors operational in 2019. Obs. $1^{\text {st }}$ income deciles comprises the $10 \%$ poorest population, while the10th decile groups the $10 \%$ wealthiest population.

\subsection{Real-estate values and the TOD in Curitiba}

As in the case of spatial distribution of high-income groups, land prices are also substantially higher in the city center. Property prices in Curitiba are considerably higher in central areas near the presence of BRT and with high construction limits (Figure 5A). The spatial organization of the real-estate market in Curitiba shows a 
clear pattern with higher priced properties nearer the North-South and East-West BRT corridors, particularly along the TOD axes.

Figure 5. (A) Spatial distribution of property values, and (B) relationship between property values and distance to the nearest BRT corridor, Curitiba, 2019.

A

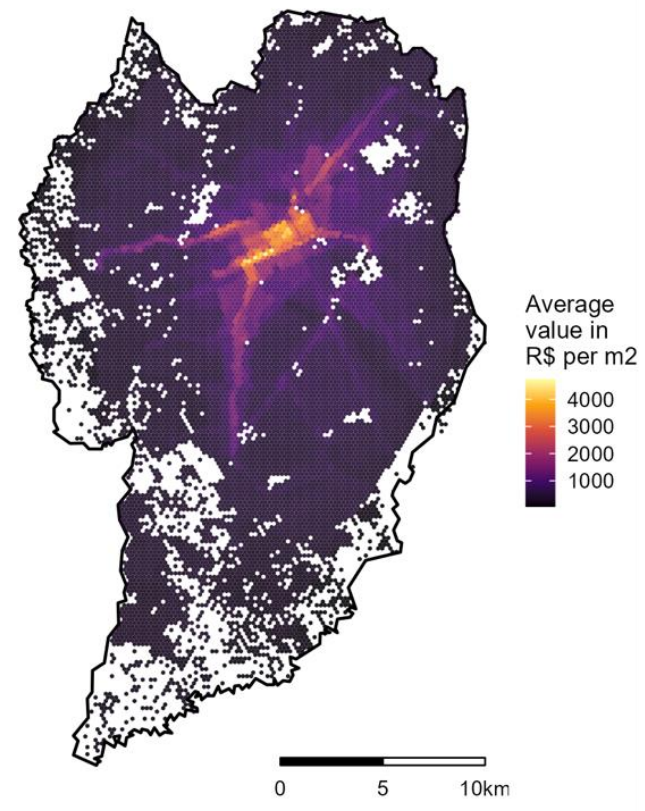

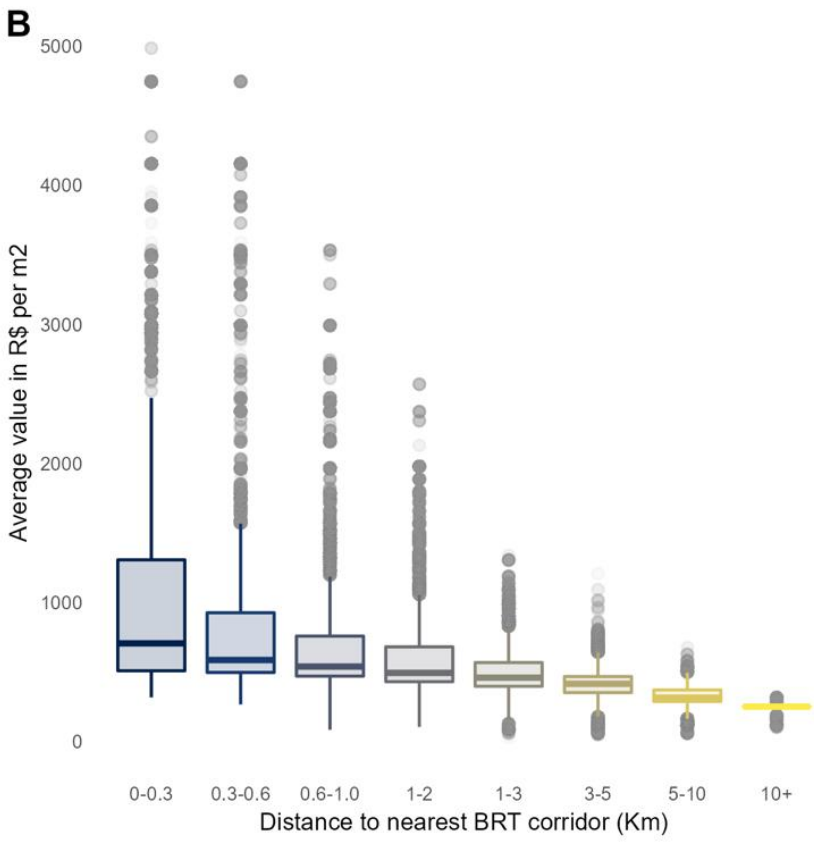

Source: population data 2010 census (IBGE) and BRT corridors operational in 2019.

\subsection{TOD and the distribution of accessibility benefits}

Public transport accessibility to employment opportunities and health services is substantially greater along the high-capacity BRT corridors that provide superior service levels and better connectivity to opportunities (Figures $6 \mathrm{~A}$ and $7 \mathrm{~A}$ ). The radial shape of Curitiba's transport system also means significantly higher network connectivity to the city center, which helps perpetuate patterns of concentration in the central regions of the city.

Concentration of high-income classes along the BRT system, coupled with peripheralization of low-income classes who cannot afford to live near TOD corridors, results in marked inequalities of access to city opportunities (Figures 6B and 7B). In 2019 , the wealthiest $10 \%$ of Curitiba's population had access to 2.6 times more jobs than the poorest $40 \%$, on average (Figure 6B). Similarly, public-transport access to 
healthcare facilities was 2.3 times higher among high-income groups compared to the poorest (Figure 7B).

Figure 6. (A) Spatial and (B) Income distribution of the percentage of job opportunities accessible by public transport in 60 minutes, Curitiba, 2019.

A

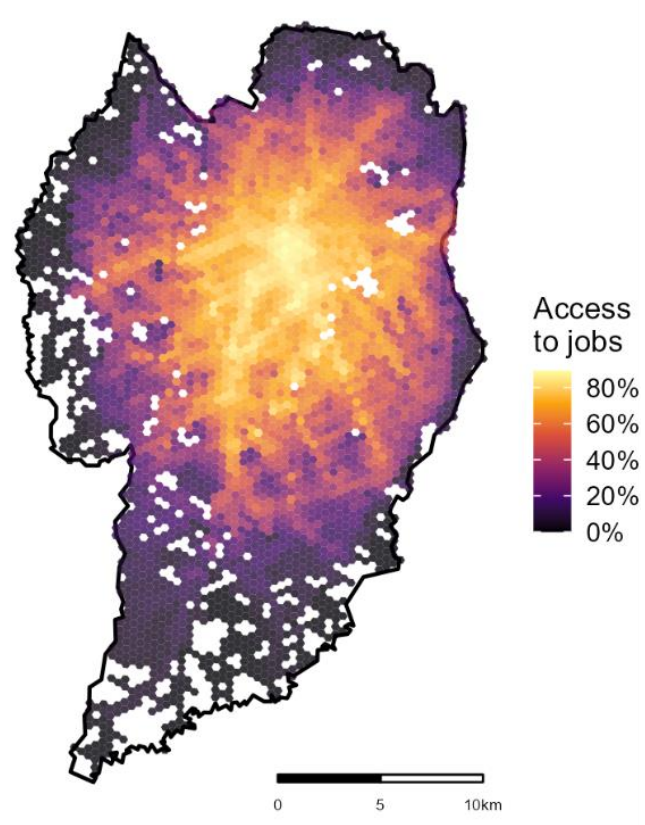

B

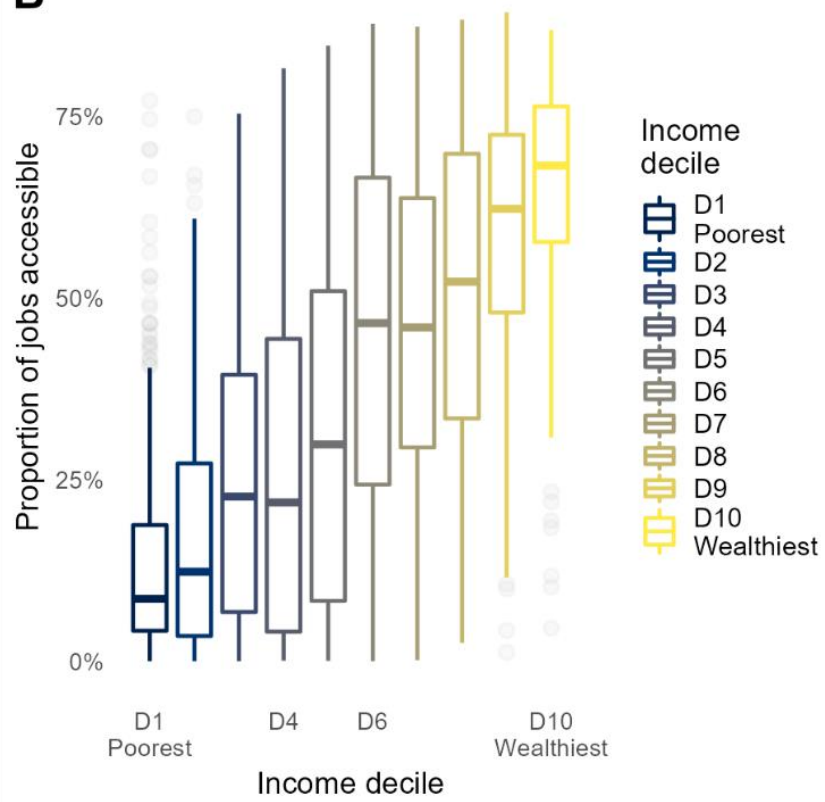

Figure 7. (A) Spatial and (B) Income distribution of the percentage of healthcare facilities accessible by public transport in 60 minutes, Curitiba, 2019.

A

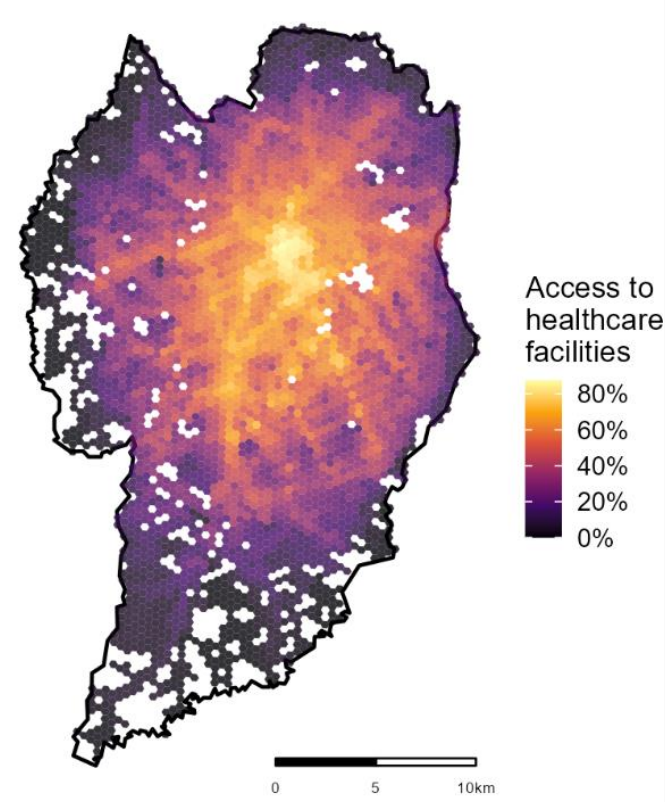

B

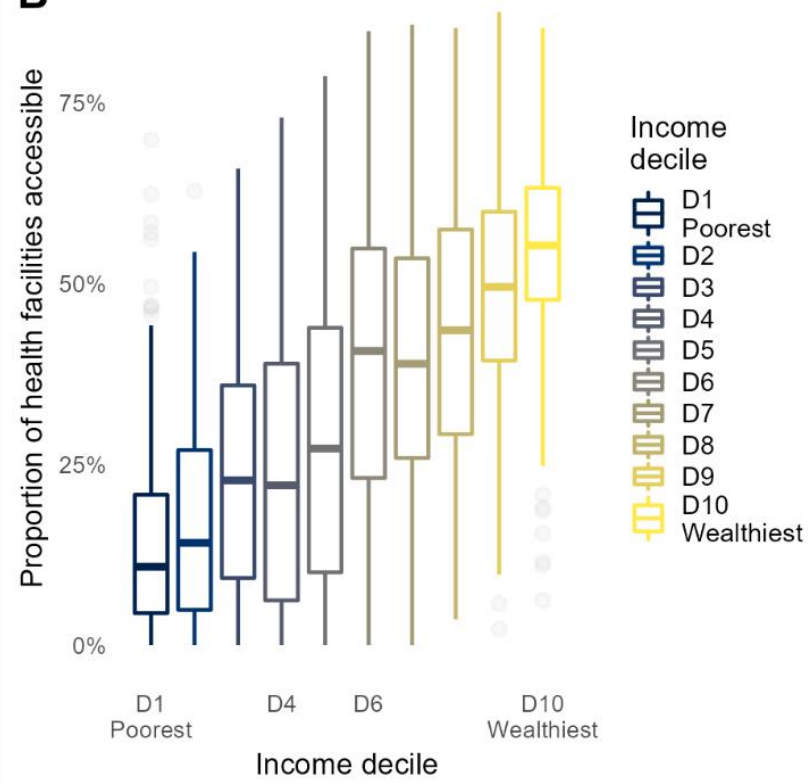


One of the most remarkable aspects of Curitiba's BRT corridors, after almost fifty years of its initial implementation, is that urban areas where the TOD is consolidated are not occupied by users of public transportation, but by users of private motorized vehicles. According to Curitiba's latest household survey data (IPPUC, 2017), the

population living along BRT corridors uses motorized private vehicles in more than $80 \%$ of their daily trips. This shows that the sole presence of TOD has very little, if any, effect on decreasing motorization. Curitiba's household survey also shows that the lower-income population (with an average income limited to one minimum wage), living in peripheral neighborhoods, travel significantly more by public transportation than by private motorized vehicles.

Another aspect to be highlighted is the remarkably higher passenger demand of the South corridor of the TOD in comparison with the other axes, particularly because this area is not marked by a high-density rate. This indicates higher stress of the public transport system in areas where the population lives further away from BRT corridors and must use other bus lines to reach the mass transit system. These are also the regions of the municipality (South and South-West) that concentrates most of the lowincome population.

In summary, the TOD in Curitiba has not been successful in defining high-density areas along the corridors, except in areas near the city center. Additionally, , the TOD contributed to the concentration of premium real estate market along BRT corridors, what contributes to push low-income communities to peripheral urban areas less served by public transport and with lower access to economic opportunities and health services.

\section{Final remarks}

This study helps to demystify the acclaimed success of Curitiba's BRT as a driver of urban sustainability, by showing that its TOD planning contributes to shape social segregation and inequalities of access to opportunities. The TOD in Curitiba has knock-on effects on land prices, that hinders the social mix purported as a TOD policy benefit, reinforcing spatial disparities between center and peripheral urban areas. The clearest effects of TOD on the spatial organization of the city are the patterns of highincome occupation and higher land prices along the corridors. The development of a 
premium real-estate market alongside TOD corridors, particularly those nearest to the center, is one of the main results of this urban policy.

The structural axes, formed by the TOD lines and special land-use policy, concentrate the BRT infrastructure and greatest building potential, which leads to higher land values in the immediate surroundings of the mass transit system. The areas nearer the city center are more consolidated, with concentrations of high-income populations alongside the TOD corridors. The areas served by TOD, but further away from the central areas are increasingly less densely occupied, with clusters of vacant land (Penteado et al., 2019) that suggests real-estate market speculation. High property values in the central area of the city and the growth of new urban densification on the periphery reflect the expansion of lower-income housing towards the periphery where real-estate is more affordable. Historically, Curitiba's TOD policies have not been able to promote socioeconomic diversity along the corridors (Duarte \& Ultramari, 2012), and has contributed to urban sprawl and social segregation.

Combined, these characteristics of the TOD policy in Curitiba have led to an unequal urban environment with important equity implications. Despite the potential to create inclusive communities, the TOD corridors in Curitiba are restricted to few limited areas that concentrate income, resources and opportunities. As a consequence, we find remarkable levels of inequalities in access to opportunities in the city. We find that access to employment opportunities and healthcare services is up to 2.6 times lower for low-income groups than for the wealthier population. This accessibility gap is partially explained by the concentration of opportunities and resources in central areas and those areas directly served by the BRT, but it is also a consequence of the peripheralization of lower-income population, pushed to regions with more affordable housing that are less served by public transport and further from the opportunities in city center.

These findings go in line with previous studies that criticize TOD projects for having exclusionary effects due to increased land prices and unequal opportunities for housing and accessibility (Saunders \& Smith, 2014; Jamme et al., 2019, Laake \& Quiñones, 2019). Our findings suggest that Curitiba's planning should be analyzed more critically, and that Curitiba's success story should be seen as a cautionary tale about the unintended consequences of TOD planning with strong coordination between transport and land-use policies. 
To mitigate the negative effects of TOD and BRT projects discussed in this paper, it is important that new similar projects in Curitiba and elsewhere adopt transport accessibility-oriented and equity goals coordinated with social housing policies. A general policy lesson from some of the BRT corridors in Curitiba is that investments in BRTs alone are not sufficient to gear urban development towards a TOD approach. In other words, the purported benefits of TOD in terms of promoting linear densification and decentralization in urban development cannot be easily achieved simply with mass transit investments. Moreover, Curitiba illustrates that even a successful case of coordination between land use policies and mass transit investments in a few BRT corridors are not sufficient to promote equitable TOD. Future TOD projects need to seriously incorporate social housing goals in to make sure that low-income families can live closer to mass transit corridors and that the transit accessibility benefits from TOD are more equitably distributed. This more integrated strategy, we argue, can be based in three dimensions: (i) mixed housing policy along BRT corridors, mainly in the non-central areas, where there is land stock, (ii) rapid transit connection with peripheral areas, where public transportation users are concentrated, and (iii) decentralization of job opportunities and services by local economic development policies in non-central areas. 


\section{References}

Allen, J. and Farber, S. (2020). Planning transport for social inclusion: An accessibilityactivity participation approach. Transportation Research Part D: Transport and Environment, 78:102212.

ANTP (2021). Associação Nacional de Transporte Público - ANTP. Redução dos tempos de viagens e custos operacionais com a implantação da Linha Direta Ligeirão Boqueirão na cidade de Curitiba. Available at http://filesserver.antp.org.br/ 5dotSystem/download/dcmDocument/2015/06/12/0D0470 FC-33D7-48D4-9B87-697CC85120DA.pdf. Access on October 12 ${ }^{\text {th }}, 2021$.

Appleyard, B.S., Frost, A.R. and Allen, C. (2019). Are all transit stations equal and equitable? Calculating sustainability, livability, health, \& equity performance of smart growth \& transit-oriented-development (TOD). Journal of Transport \& Health, 14, p.100584. https://doi.org/10.1016/j.jth.2019.100584

Ardila-Gómez, A. (2004). Transit planning in Curitiba and Bogotá. Roles in interaction, risk, and change. Unpublished Ph. D. dissertation, Massachusetts Institute of Technology.

Banister, D. (2011). The trilogy of distance, speed and time. Journal of Transport Geography, 19(4), 950-959.

Bernick, M. and Cervero, R. (1997). Transit villages in the 21st century.

Bittencourt, T. A., Giannotti, M., \& Marques, E. (2020). Cumulative (and selfreinforcing) spatial inequalities: interactions between accessibility and segregation in four Brazilian metropolises. Environment and Planning B: Urban Analytics and City Science, 2399808320958426.

Boisjoly, G.; El-Geneidy, A.M. (2017). How to get there? A critical assessment of accessibility objectives and indicators in metropolitan transportation plans. Transport Policy, 55, pp.38-50. https://doi.org/10.1016/j.tranpol.2016.12.011

Boisjoly, G., Serra, B., Oliveira, G.T. and El-Geneidy, A. (2020). Accessibility measurements in São Paulo, Rio de Janeiro, Curitiba and Recife, Brazil. Journal of Transport Geography, 82, p.102551. https://doi.org/10.1016/j.jtrangeo.2019.102551

Boschmann, E. E. and Brady, S. A. (2013). Travel behaviors, sustainable mobility, and transit-oriented developments: a travel counts analysis of older adults in the 
Denver, Colorado metropolitan area. Journal of Transport Geography, 33, pp.111. https://doi.org/10.1016/j.jtrangeo.2013.09.001

Calthorpe, P. (1994). The next American metropolis. Architectural Design, (108), pp.18-23.

Carlton, I. (2009). Transit infrastructure finance through station location auctions (No. 2009, 04). Working Paper.

Cervero, R. (1998). The transit metropolis: a global inquiry. Island press.

Cervero, R. and Sullivan, C. (2011). Green TODs: marrying transit-oriented development and green urbanism. International journal of sustainable development \& world ecology, 18(3), pp.210-218. https://doi.org/10.1080/13504509.2011.570801

Cervero, R. (2014). Transport infrastructure and the environment in the global South: sustainable mobility and urbanism. Journal of Regional and City Planning, 25(3), pp.174-191. https://doi.org/10.5614/jpwk.2015.25.3.1

Cervero, R., \& Dai, D. (2014). BRT TOD: Leveraging transit-oriented development with bus rapid transit investments. Transport Policy, 36, 127-138. https://doi.org/10.1016/j.tranpol.2014.08.001

Chava, J., Newman, P. and Tiwari, R. (2018). Gentrification of station areas and its impact on transit ridership. Case Studies on Transport Policy, 6(1), pp.1-10.

https://doi.org/10.1016/i.cstp.2018.01.007

Curitiba (1965). Plano Preliminar de Urbanismo de Curitiba. Prefeitura Municipal de Curitiba. Available at http://www.ippuc.org.br/visualizar.php?doc=https://ippuc.org.br/arquivos/site//l tdocumentos/D12/D12 010 BR.pdf. Access on October, 24 ${ }^{\text {th }}, 2021$.

Curitiba (1966). Prefeitura Municipal de Curitiba. Plano Diretor de Curitiba, Lei № 2.828, de 1966. Available at https://leismunicipais.com.br/a/pr/c/curitiba/leiordinaria/1966/282/2828/lei-ordinaria-n-2828-1966-institui-o-plano-diretor-decuritiba-e-aprova-as-suas-diretrizes-basicas-para-orientacao-e-controle-dodesenvolvimento-integrado-do-municipio-revogando-as-leis-n-1875-60-1-95160-1-908-60-2-100-61-2-123-61-2-15462\#: :text=\%22INSTITUI\%200\%20PLANO\%20DIRETOR\%20DE,62\%3B\%2 02154\%2F62.\%22. Access on August 11 ${ }^{\text {th }}, 2021$. 
Curitiba (2015). Prefeitura Municipal de Curitiba. Plano Diretor de Curitiba, Lei № 14.771, de 17 de dezembro de 2015. Available at https://mid.curitiba.pr.gov.br/2015/00175701.pdf. Access on September 10 2021.

Curitiba (2020). Prefeitura Municipal de Curitiba. Plano de Ação Climática de Curitiba, dezembro de 2020.2 Available at https://mid.curitiba.pr.gov.br/2020/00306556.pdf. Access on November $10^{\text {th }}$, 2021.

Curitiba (2020). Prefeitura Municipal de Curitiba. Decreto N. 1731 de 2020. Available at https://mid.curitiba.pr.gov.br/2021/00312124.pdf. Access on October, $12^{\text {th }}$, 2021.

de Freitas Miranda, H. and da Silva, A.N.R. (2012). Benchmarking sustainable urban mobility: The case of Curitiba, Brazil. Transport Policy, 21, pp.141-151. https://doi.org/10.1016/i.tranpol.2012.03.009

Deboosere, R., El-Geneidy, A.M. and Levinson, D. (2018). Accessibility-oriented development. Journal of Transport Geography, 70, pp.11-20. https://doi.org/10.1016/i.jtrangeo.2018.05.015

Dittmar, H. and Poticha, S. (2004). Defining transit-oriented development: The new regional building block. The new transit town: best practices in transit-oriented development, pp.19-40.

Duarte, F., Firmino, R. and Prestes, O. (2011). Learning from failures: Avoiding asymmetrical views of public transportation initiatives in Curitiba. Journal of Urban Technology, 18(3), pp.81-100. https://doi.org/10.1080/10630732.2011.615569

Duarte, F. and Rojas, F. (2012). Intermodal connectivity to BRT: a comparative analysis of Bogotá and Curitiba. Journal of Public Transportation, 15(2), p.1. http://doi.org/10.5038/2375-0901.15.2.1

Duarte, F. and Ultramari, C. (2012). Making public transport and housing match: Accomplishments and failures of Curitba's BRT. Journal of Urban Planning and Development, 138(2), pp.183-194. https://doi.org/10.1061/(ASCE)UP.1943$\underline{5444.0000107}$ 
Feitelson, E. (2002). Introducing environmental equity dimensions into the sustainable transport discourse: Issues and pitfalls. Transportation Research Part D: Transport and Environment, 7(2):99-118

Fol, S. and Gallez, C. (2014). Social inequalities in urban access: better ways of assessing transport improvements. In Urban Access for the 21st Century (pp. 46-86). Routledge.

Follador, D., Duarte, F., \& Carrier, M. (2018). Informal institutions and path dependence in urban planning: The case of Curitiba, Brazil. Journal of Urban Affairs, 1-20. https://doi.org/10.1080/07352166.2018.1495040

Geurs, K.T., De Montis, A. and Reggiani, A. (2015). Recent advances and applications in accessibility modelling. Computers, environment and urban systems, 49, pp.82-85. https://doi.org/10.1016/j.compenvurbsys.2014.09.003

Handy, S. (2020). Is accessibility an idea whose time has finally come? Transportation Research Part D: Transport and Environment, 83:102319.

Hidalgo, D.; Laake, T. V.; Quiñones, L. M. (2019). Overcoming constraints to improve BRT in Latin America. In Moscoso, M., T. van Laake, \& L. Quiñones, Eds. (2019). Sustainable Urban Mobility in Latin America: assessment and recommendations for mobility policies. Despacio: Bogotá, Colombia.

IBGE (1997). Instituto Brasileiro de Geografia e Estatística - IBGE. Demográfico, I. C. Contagem da População 1996. Rio de Janeiro.

IBGE (2010). Instituto Brasileiro de Geografia e Estatística - IBGE. Sinopse do Censo Demográfico $2010 . \quad$ Available at https://censo2010.ibge.gov.br/sinopse/index.php?dados $=6$. Access on November 11th, 2021.

IBGE (2016). Instituto Brasileiro de Geografia e Estatística - IBGE. Grade estatística 2010. 2016. Disponível em: <https://bit.ly/2rU73IL>.

IBGE (2021). Instituto Brasileiro de Geografia e Estatística - IBGE. Curitiba-PR IBGE Cidades. Available at https://cidades.ibge.gov.br/brasil/pr/curitiba/panorama. Access on November 11th, 2021.

Iclei (2016). ICLEI Case Study: Curitiba, Brazil, A model for Transit Oriented Development. February 24, 2016. Disponível em https://urban-leds.org/wpcontent/uploads/2019/resources/case_studies/ICLEI_cs_190_Curitiba_UrbanLEDS.pdf. Acesso em 20 de junho de 2021. 
IPPUC (2012). Instituto de Pesquisa e Planejamento Urbano de Curitiba - IPPUC. Evolução da Ocupação Urbana. Curitiba: IPPUC, 2012. Available at https://ippuc.org.br/visualizar.php?doc=https://admsite2013.ippuc.org.br/arqui vos/documentos/D353/D353 007 BR.pdf. Access on November 2nd, 2021.

IPPUC (2017). Consolidação de dados de oferta, demanda, sistema viário e zoneamento - Relatório 5 pesquisa origem-destino domiciliar. Instituto de Pesquisa e Planejamento Urbano de Curitiba (IPPUC). Available at https://ippuc.org.br/visualizar.php?doc=https://admsite2013.ippuc.org.br/arqui vos/documentos/D536/D536 002 BR.pdf

Jamme, H.T., Rodriguez, J., Bahl, D. and Banerjee, T. (2019). A Twenty-Five-Year Biography of the TOD Concept: From Design to Policy, Planning, and Implementation. Journal of Planning Education and Research, 39(4), pp.409428. https://doi.org/10.1177/0739456X19882073

Khayesi, M. and Amekudzi, A.A. (2011). Kingdon's multiple streams model and automobile dependence reversal path: the case of Curitiba, Brazil. Journal of Transport Geography, 19(6), pp.1547-1552. https://doi.org/10.1016/i.jtrangeo.2011.06.012

Laake, V. T. and Quiñones, L. M. (2019). Sustainable transport in Latin America: from discourse to reality. In Moscoso, M., T. van Laake, \& L. Quiñones, Eds. (2019). Sustainable Urban Mobility in Latin America: assessment and recommendations for mobility policies. Despacio: Bogotá, Colombia.

Levine, J. (2020). A century of evolution of the accessibility concept. Transportation Research Part D

Levinson, D., \& King, D. (2020). Transport Access Manual: A Guide for Measuring Connection between People and Places. Committee of the Transport Access Manual, University of Sydney. https://hdl.handle.net/2123/23733

Lindau, L.A., Hidalgo, D. and Facchini, D. (2010). Curitiba, the cradle of bus rapid transit. Built Environment, 36(3), pp.274-282. https://doi.org/10.2148/benv.36.3.274

Loo, B.P. and du Verle, F. (2017). Transit-oriented development in future cities: Towards a two-level sustainable mobility strategy. International Journal of Urban Sciences, 21(sup1), pp.54-67. https://doi.org/10.1080/12265934.2016.1235488 
Lucas, K., van Wee, B., and Maat, K. (2016). A method to evaluate equitable accessibility: combining ethical theories and accessibility-based approaches. Transportation, 43(3):473-490.

Lyu, G., Bertolini, L. and Pfeffer, K. (2020). How does transit-oriented development contribute to station area accessibility? A study in Beijing. International journal of sustainable transportation, 14(7), pp.533-543. https://doi.org/10.1080/15568318.2019.1578841

Macedo, J. (2004). Curitiba. Cities, 21(6), pp.537-549. https://doi.org/10.1016/j.cities.2004.08.008

Manaugh, K., Badami, M. G. and El-Geneidy, A. M. (2015). Integrating social equity into urban transportation planning: A critical evaluation of equity objectives and measures in transportation plans in North America. Transport Policy, 37, 167176. https://doi.org/10.1016/j.tranpol.2014.09.013

Martens, K. (2016). Transport Justice: Designing Fair Transportation Systems. Routledge, London.

Mattioli, G. (2016). Transport needs in a climate-constrained world. A novel framework to reconcile social and environmental sustainability in transport. Energy Res. Soc. Sci. 18, 118-128, doi:10.1016/j.erss.2016.03.025.

Mercier, J., Duarte, F., Domingue, J. and Carrier, M. (2015). Understanding continuity in sustainable transport planning in Curitiba. Urban Studies, 52(8), pp.14541470. https://doi.org/10.1177/0042098014538526

Miralles-Guasch, C. and Frontera, À.C. (2003). Movilidad y transporte: opciones políticas para la ciudad. Madrid: Fundación alternativas.

Nakamura, F., Makimura, K. and Toyama, Y. (2017). Perspective on an urban transportation strategy with BRT for developing cities. Engineering and Applied Science Research, 44(3), pp.196-201.

Oba, L. T. (2004). Cidade grifada: Curitiba e seus eixos estruturais. Encontro Anual Associação Nacional de Pós Graduação e Pesquisa em Ambiente e Sociedade-ANPPAS, Indaiatuba. Anais do II Encontro. ANPPAS Brasil.

OM (2019). OM - Observatório das Metrópoles. Mapa da motorização Individual no Brasil, 2019. Available at https://www.observatoriodasmetropoles.net.br/wpcontent/uploads/2019/09/ma pa moto2019v2.pdf. Access on January 10 2021. 
OXFAM (2017). Latin America remains the most unequal region in the world, 2017. Available at https://blogs.oxfam.org/en/blogs/17-12-18-latin-america-remainsmost-unequal-region-world/index.html. Access on January 12t $\mathrm{t}^{\mathrm{h}}, 2021$.

Padeiro, M., Louro, A. and da Costa, N.M. (2019). Transit-oriented development and gentrification: a systematic review. Transport Reviews, 39(6), pp.733-754. https://doi.org/10.1080/01441647.2019.1649316

Papa, E., and Bertolini, L. (2015). Accessibility and transit-oriented development in European metropolitan areas. Journal of Transport Geography, 47, 70-83. https://doi.org/10.1016/j.jtrangeo.2015.07.003

Penteado, A.D., Pereira, G. and Maziviero, M.C. (2019). Vazios urbanos: perspectivas para o Setor Estrutural Norte de Curitiba. Arquitetura e Cidade: privilégios, conflitos e possibilidades, Curitiba, 2019. Available at http://projedata.grupoprojetar.ct.ufrn.br/dspace/bitstream/handle/123456789/1 267/ ARTIGO ProjetarCuritiba2019 Vazios\%20urbanos\%20perspectivas\%2 Opara\%200\%20Setor\%20Estrutural\%20Norte\%20de\%20Curitiba.pdf?sequen $\mathrm{ce}=1$ \&isAllowed $=\mathrm{y}$. Access on August 29th, 2021.

Pereira, R. H., Schwanen, T., \& Banister, D. (2017). Distributive justice and equity in transportation. Transport $\quad$ reviews, 37(2), 170-191. https://doi.org/10.1080/01441647.2016.1257660

Pereira, R.H., Banister, D., Schwanen, T. and Wessel, N. (2017). Distributional effects of transport policies on inequalities in access to opportunities in Rio de Janeiro. Journal of Transport and Land Use, 12(1), pp.741-764. https://doi.org/10.31235/osf.io/cghx2

Pereira, R. H. M., Braga, C. K. V., Serra, Bernardo, \& Nadalin, V. (2019). Desigualdades socioespaciais de acesso a oportunidades nas cidades brasileiras, 2019 (№ 2535; Texto para Discussão IPEA). Instituto de Pesquisa Econômica Aplicada Ipea. http://www.ipea.gov.br/portal/images/stories/PDFs/TDs/td 2535.pdf

Pereira, R. H. M., \& Karner, Alex. (2021). Transportation equity. In R. Vickerman, International Encyclopedia of Transportation (1st Edition, Vol. 1, p. 271-277). Elsevier. $\quad$ https://www.elsevier.com/books/international-encyclopedia-oftransportation/vickerman/978-0-08-102671-7 
Perk, V.A. and Catala, M. (2009). Land use impacts of bus rapid transit: effects of BRT station proximity on property values along the Pittsburgh Martin Luther King, Jr. East Busway (No. FTA-FL-26-7109.2009. 6).

PMI (2019). PMI - Project Management Institute. Curitiba BRT: For Sparking a Transportation Revolution in Cities around the World (Most Influential Projects: \#33). PM Network, 33, 68-69. https://www.pmi.org/learning/library/top-50projects-curitiba-brt-11763.

Polucha, R. S. (2009). Ecoville: construindo uma cidade para poucos. Revista Brasileira de Estudos Urbanos e Regionais, v. 11, n. 1, p. 41-41.

Qviström, M. and Bengtsson, J. (2015). What kind of transit-oriented development? Using planning history to differentiate a model for sustainable development. European Planning Studies, 23(12), pp.2516-2534. https://doi.org/10.1080/09654313.2015.1016900

Rabinovitch, J. and Leitman, J. (1996). Urban planning in Curitiba. Scientific American, 274(3), 46-53.

Renne, J. L., Hamidi, S., \& Ewing, R. (2016). Transit commuting, the network accessibility effect, and the built environment in station areas across the United States. Research in Transportation Economics, 60, 35-43.

Saunders, B. and Smith, K. (2014). Quality of Life, (E)Quality of Place: Growing Local Economies through Equitable Transit-Oriented Development.

Stewart, A.F. (2014). Visualizing urban accessibility metrics for incremental bus rapid transit projects (Doctoral dissertation, Massachusetts Institute of Technology).

Suzuki, H., Cervero, R. and luchi, K. (2013). Transforming cities with transit: Transit and land-use integration for sustainable urban development. World Bank Publications.

Taki, H.M., Maatouk, M.M.H., Qurnfulah, E.M. and Aljoufie, M.O. (2017). Planning TOD with land use and transport integration: a review. Journal of Geoscience, Engineering, Environment, and Technology, 2(1), pp.84-94. https://doi.org/10.24273/jgeet.2017.2.1.17

URBS (2022). URBS - Urbanização de Curitiba S. A. Estatísticas do transporte, número de viagens realizadas pelos ônibus da RIT. Available at https://www.urbs.curitiba.pr.gov.br/transporte/estatisticas/viagens. Access on April 04 ${ }^{\text {th }}, 2021$. 
URBS (2021). URBS - Urbanização de Curitiba S. A. História do transporte. Available at https://www.urbs.curitiba.pr.gov.br/transporte/historia-transporte. Access on October 20 2021.

Van Wee, B. and Geurs, K. (2011). Discussing equity and social exclusion in accessibility evaluations. European journal of transport and infrastructure research, 11(4). https://doi.org/10.18757/ejtir.2011.11.4.2940

Van Wee, B. (2016). Accessible accessibility research challenges. Journal of transport geography, 51, pp.9-16. https://doi.org/10.1016/i.jtrangeo.2015.10.018

Venter, C., Jennings, G., Hidalgo, D., \& Valderrama Pineda, A. F. (2018). The equity impacts of bus rapid transit: A review of the evidence and implications for sustainable transport. International Journal of Sustainable Transportation, 12(2), 140-152.

Verlinghieri, E. and Schwanen, T. (2020). Transport and mobility justice: Evolving discussions. journal of transport geography, 87, 102798.

Xu, Y., Belyi, A., Bojic, I. and Ratti, C. (2018). Human mobility and socioeconomic status: Analysis of Singapore and Boston. Computers, Environment and Urban Systems, 72, pp.51-67. https://doi.org/10.1016/i.compenvurbsys.2018.04.001 